\title{
Disputes in the Arctic: Threats and Opportunities
}

\author{
Nikoloz Janjgava *
}

\section{Introduction}

For centuries, the Arctic was a "sacred place" for humanity. This frozen void was a magnet for adventurers and explorers, for everybody who wanted to challenge both themselves and nature. In nineteenth century, the "top of the world" became a field of competition for major European and North American nations. During this race, the main prize was the North Pole. Which state would be the first to claim it? Even at the climax of the era of colonial conquest, no nation was ready to declare the Arctic entirely for itself. The twentieth century brought new developments to the Arctic. Two World Wars went almost unnoticed in the extreme North. But during the Cold War, the Arctic became a new battleground. For two superpowers - the United States and the Soviet Union - the route through the Arctic provided the shortest course for nuclear-armed intercontinental missiles and planes loaded with thermonuclear bombs bound for targets in one nation or the other. The thick ice cap provided additional protection for the nuclear submarines trying to edge ever closer to enemy territory. After the end of Cold War and the collapse of communism in Eastern Europe, the attention given to the Arctic waned. With the beginning of the twenty-first century, new challenges arose in the Arctic. Climate change, a global race for natural resources, new transportation routes, and old territorial disputes created not only new threats to security, but also opportunities for cooperation between the Arctic countries.

The purpose of this article is to examine the problems that have arisen in the Arctic in the post-Cold War era. This essay will analyze the role of the major players in the Arctic; the territorial disputes between the Arctic countries; sovereign rights over natural resources; and disputes over new transportation routes. It is particularly important to examine Russia's military build-up and its more assertive foreign policy in the Arctic region.

There are two main reasons why the Arctic has increasingly come to take a place at the center of global politics. The first reason is climate change. The process of global warming is a byproduct of human activities, yet up to this point the global community has failed to establish common rules to reduce the use of fossil fuels and reduce carbon emissions in order to reduce the effects of climate change. Melting of year-round sea ice in the Arctic has opened completely new sea routes, and the reduction in size of the polar ice cap in the Arctic has uncovered natural resources that were hidden for millennia. The second reason is the rise of Russia. Even before the war with Georgia in 2008, Rus-

\footnotetext{
Col. Nikoloz Janjgava is an International Fellow at the National War College in the National Defense University in Washington, D.C. His primary appointment is in the Georgian military. The views expressed in this article are those of the author and do not reflect the official policy or position of the National Defense University, the Department of Defense, or the U.S. Government.
} 
sia had been demonstrating that it was coming to rely more on "hard power" than on the primacy of international law. By stepping up its nationalistic rhetoric and increasingly acting unilaterally, Russia's political and military leadership is trying to reassess and create a vision for a "New Russia."

\section{The Major Players}

There are five "Arctic Rim" countries: the United States, Canada, Denmark (through its possession of Greenland), Norway, and Russia. In addition, there are three more nations with territory bordering or above the Arctic Circle: Iceland, Sweden, and Finland. By extension, the European Union (EU) is a major stakeholder in all Arctic disputes (given Denmark, Sweden, and Finland's status as EU members). These eight countries are members of the Arctic Council. This high-level forum was established in 1996 to increase cooperation between the Arctic countries. There are six working groups that administer a range of projects - from regulations on shipping in the "High North" to assessments of the impact of climate change. The Arctic Council works by consensus, and has no regulatory mandate nor any enforcement mechanism. ${ }^{1}$ Germany, Poland, the Netherlands, France, Spain, and Great Britain hold the status of permanent observers. China, Japan, South Korea, and Italy all hold ad hoc observer status. These countries are far away from the Arctic, but they are interested in participating in the work of the Arctic Council to formulate shipping rights (which can affect their transportation networks) and to take part in the exploitation of the natural resources of the Arctic.

\section{Territorial Disputes}

Disputed boundaries represent the major security challenge for the countries that border each other in the Arctic. These include not only border disputes, but also the questions of passage rights, domestic and international waters, the length of the continental shelf, and the boundaries of the Exclusive Economic Zones (EEZ).

There are two main international laws that provide principles for the nations to settle their differences: the 1958 Continental Shelf Convention and the 1982 UN Law of the Sea Convention (UNLSC). The UNLSC establishes that coastal states have sovereign rights over the natural resources within 200 nautical miles from their baselines. This extended boundary represents their Exclusive Economic Zone. Beyond the EEZ lays the high seas, where the rights of free shipping and flag rights apply. The most problematic question is where the continental shelf starts and where it ends. According to the UNLSC, after the end point of the 200 nautical mile boundary, a country's jurisdiction on the continental shelf extends until it becomes the deep seabed. The mineral resources in the deep sea belong to all of mankind. To claim their rights over the continental shelf,

1 Alf Håkon Hoel, "The High North Legal-Political Regime," in Security Prospects in the High North: Geostrategic Thaw or Freeze?, ed. Sven Holtsmark and Brooke Smith-Windsor (Rome: NATO Defense College, May 2009), 95. 
countries must submit the relevant information to the UN Continental Shelf Commission. $^{2}$

Questions regarding the delimitation of national boundaries and the respective Exclusive Economic Zones affect almost all Arctic countries. For example, disputes currently exist between Russia and the U.S. regarding the Bering Sea; the U.S and Canada over the Beaufort Sea; Canada and Denmark concerning the Davis Straits; Denmark and Iceland with respect to the Fram Strait; Denmark and Norway and Iceland over the status of Jan Mayen Island; and Denmark and Norway regarding Svalbard Island. The dispute between Norway and Russia over maritime boundaries in the Barents Sea was settled by an agreement in September 2010. The forty-year dispute over an area of more than 175,000 square kilometers between Russia's Kola Peninsula and Norway's coast was equally divided by both countries. Another territorial dispute exists between Canada and Denmark over uninhibited Hans Island, where both sides have routinely raised their respective flags. In 2005, the Danish Prime Minister declared: "Let us together use Hans Island as a symbol of peace and goodwill to show how civilized nations treat each other with respect." ${ }^{3}$ But the problem of sovereignty rights over Hans Island remains unresolved.

\section{New Shipping Routes}

Issues regarding the boundaries of territorial waters are tied up with the rights of free shipping and free passage of straits. With the melting of the year-round sea ice, two new Arctic passages may soon be open for navigation. Climatologists are predicting the possibility of an ice-free Arctic Ocean as early as 2015. The opening of these two passages - the Northwest and the Northeast - will significantly shorten the sea navigation lines between the continents. The Northwest Passage stretches from Lancaster Sound to the Bering Straits. The Northeast Passage (or the Northern Sea Route, as it is called by Russians) follows the Siberian coast. The main differences between the two passages are that the Northwest Passage lays entirely in Canadian-claimed waters, while the Northeast Passage lies primary in Russia's EEZ. ${ }^{4}$

For the United States, the freedom of sea transportation and communication lines is one of the top national security priorities. The U.S. did not sign the UNLSC, and considers both passages to be in international waters that cannot be regulated by national laws. This position creates tensions not only with Russia, but also with the United States' neighbor and long-time ally Canada. In November 2009, Russia announced that it would charge ships a 'fair' price to travel the Northeast Passage; ships must submit a notification in advance and file an application for guidance - all under Russian jurisdic-

2 Ibid., 87.

3 Michael Byers, Who Owns the Arctic? Understanding Sovereignty Disputes in the North (Vancouver, BC: Douglas \& McIntyre, 2010), 30.

4 Frédéric Lasserre, "High North Shipping: Myths and Realities," in Security Prospects in the High North, 179. 
tion. As for the Northwest Passage, Canada claims it as an "inland sea," which falls entirely under Canadian sovereignty. ${ }^{5}$

The effects of climate change will play a vital role in this part of the world. Melting ice open passages between continents that before were completely ignored. The distances connecting Europe and Asia across the Northwest (NWP) or Northeast Passages (NEP) are much shorter than routes going through the Suez and Panama Canals. From Rotterdam to Yokohama, the distance is $13,950 \mathrm{~km}$ through the NWP and 13,360 km through the NEP, compared to $23,470 \mathrm{~km}$ through the Panama Canal and 21,170 km across the Suez Canal. ${ }^{6}$

There are also other factors in addition to distance that will affect decisions about navigation. The main disadvantage of both passages is that they are extremely difficult to navigate, with ice and sub-zero temperatures during the long Arctic winter. Drifting ice and icebergs will present hazards for navigation. Several straits have a low draft (as low as 13 meters, which will present a problem for large cargo ships), and the harbor infrastructure for stopovers for oceangoing ships is not developed. For shipping firms, time is the most valuable commodity; any delays by either natural or man-made hazards could affect the costs of shipping. The price of insurance will be higher. The new hullstrengthened ships with powerful night vision and radar capabilities that are necessary to navigate such perilous waters will drive up the costs of shipping even further. Those are only a few of the constraints that might affect shipping across the Northwest and Northeast Passages.

\section{Rights over Natural Resources in the Arctic}

The Arctic is critically important for the availability of its natural resources. In 2008, the U.S. Geological Society (USGS) estimated that about 22 percent of the world's undiscovered recoverable oil and gas resources lie beneath the Arctic. The region holds 83 billion barrels of oil, which is enough to meet global demand for three years. Gas deposits of 44 trillion cubic meters are equivalent to fourteen years of supply. The Russian Gazprom monopoly is spending USD 20 billion developing the Stockman gas field, which holds an estimated 3.8 trillion cubic meters of natural gas. Norwegian firms are exploiting the sizable (but smaller) Shovit field. Canadian and British firms are investing USD 1.2 billion on the Canadian side of the Beaufort Sea. ${ }^{7}$

The energy security problem derives from two major concerns: the uneven distribution of natural resources between the Arctic states and the fact of unsettled borders. But according to the USGS assessment, the majority of the Arctic's oil and gas resources lay within the undisputed Exclusive Economic Zones of the Arctic states. The biggest proven reserve, the East Siberian gas and oil field, lies entirely within the Russian EEZ. An agreement was signed between Norway and Russia in order to define the borders in

5 Stephen Blank, Russia in the Arctic (Carlisle, PA: Strategic Studies Institute Papers, U.S. Army War College, 2011), 27.

6 Lasserre, "High North Shipping: Myths and Realities," 193.

7 Byers, Who Owns the Arctic?, 10. 
the Barents Sea, with its prospective gas and oil reserves. But there are also major problems in the exploration of these resources. From the perspective of industry interests, the major oil companies are assessing the feasibility of the region in terms of resource potential, technological challenges, and costs and risks. The current activities of the oil/gas companies in Arctic region are mostly confined to onshore drilling. Even the oil reserves are at a depth of no more than 500 meters, which makes offshore drilling a very cost-effective business. Most of the unexplored resources are located under the ice cap, where the harsh weather conditions, combined with the cycle of drilling, excavation, and transportation in an environment with almost no infrastructure base, makes these endeavors very expensive. Oil and gas exploration is market-driven. The cost of a barrel of oil drilled in the Arctic ranges from USD 40 to 100, compared to USD 10 to 40 for a barrel of oil from the Middle East and North Africa. ${ }^{8}$ The future development of the Arctic as a field for energy exploration depends on the continued rise of demand and prices, as well as on technological breakthroughs and political developments in the Arctic countries, especially in the Russian Federation.

\section{The Russian Strategy Towards the Arctic}

The High North has always held a special place within the strategic decision making of the Russian political and military establishment. After the collapse of the Soviet Union and the following period of fiscal austerity, the Russian Arctic (and especially its Northern Fleet) received new attention from Moscow's ruling élites. The idea of the Arctic as a strategic bastion was first put forth by the Russian Admiral Sergey Gorshkov. During the Soviet era, the backbone of the military's doctrine was a reliance on land-based intercontinental ballistic missiles (ICBMs). Now, however, submarine-based "retaliation forces" represent Moscow's main area of emphasis. Even during the hard times of the 1990s, the Russian Northern Fleet always received sufficient finances to keep its nuclear submarines and infrastructure operational. The nuclear deterrent is a key element in Russian security policy, and serves as a symbol of Russia's superpower status. The most important sea-based nuclear forces operate from the Kola Peninsula, above the Arctic Circle.

At present the strength of the Russian Northern Fleet consists of eleven strategic submarines, three nuclear submarines with cruise missiles, more than seventy ships of different ranks, one marine infantry brigade, and more than eighty aircraft. All bases of the Northern Fleet are located in the Arctic, mostly in the Murmansk region. It is also important to mention that Russia possesses a formidable fleet of seven nuclear-powered ice breakers, a fleet that Russia hopes to expand to fourteen by $2020 .{ }^{9}$

In 2007, President Putin ordered the resumption of regular air patrols over the Arctic Ocean. Strategic bombers (Tu-95, Tu-160) and long-range anti-submarine patrol aircraft (Tu-142) began conducting patrols. In 2007, Russian bombers penetrated North Ameri-

8 Kristine Offerdal, "High North Energy: Myths and Realities," in Security Prospects in the High North, 169.

9 Blank, Russia in the Arctic, 80. 
can Aerospace Defense Command (NORAD) controlled airspace eighteen times. In February 2009, two Tu-95 bombers entered the airspace of Canada, just one day before an official visit by U.S. President Barack Obama. ${ }^{10}$ In August 2009, two Russian attack submarines of the Project 971, Shuka-B class were sent on patrol in close proximity to Canadian borders. General Shamanov, who was in charge of military training in the Russian General Staff, declared: "after the reaction to Russia's territorial claims in the Arctic, my division immediately started planning for the training for troops that could be engaged in Arctic combat missions."11

Also in 2007, a Russian mini-submarine submerged to the depth of 4000 meters in the Arctic and planted the Russian flag on the sea floor. "The High North is Russian. We will not give it to anybody!" declared Artur Chilingarov, the famous Polar explorer and member of the ruling United Russia party. In September 2008, the Russian Security Council adopted a document titled "The Fundamentals of Russian State Policy in the Arctic up to 2020 and Beyond." This document sets forth the state's intention to strengthen Russian positions in the region by deploying the military and border security troops to guarantee the security of Russia's Arctic territory. The National Security Strategy, which was adopted in 2009 and signed by then-President Medvedev, defines the Arctic as a strategic region for Russia's security. This document outlined the necessity of creating military units in order to defend the High North. The list of other priorities identified includes exploitation of the region's natural resources; securing Russia's national interests on the continental shelf; and developing the infrastructure and promoting navigation through the Northeast Passage. Russia insists on its legal right to the seabed as a continuation of its continental shelf. The UN Commission on the Limits of the Continental Shelf asked Russia to present more specific geological and geophysical evidence that the Lomonosov and Mendeleev ridges are extensions of Russia's continental shelf. The next deadline is in 2013. If it is approved, Russia will be in full possession of the Northeast Passage, as well as significant parts of the Arctic Ocean and tremendous deposits of oil and natural gas. ${ }^{12}$

The perception that the U.S. and NATO are the major threats to Russia's national security is deeply imbedded in the Russian political and military establishment. The Russian leadership suspects that the Western countries have a hidden agenda, and that they want to challenge or even displace Russia as a major player in the Arctic. Russia's renationalization of its energy sector from foreign ownership is one of the steps that Moscow has taken to minimize its dependency on the West. But Russia still desperately needs Foreign Direct Investments (FDI) in its economy, especially in the fields of technology and modernization of oil and gas industries. So far, Russian military ambition in the region has been more rhetoric than reality. Most of the nationalistic fervor was targeted for domestic consumption, to show that Putin-Medvedev 'tandem' were the only true patriots. During Medvedev's presidency, the main concerns were the global economic crisis,

10 Byers, Who Owns the Arctic?, 11.

11 Blank, Russia in the Arctic, 44.

12 Ibid., 49. 
the 'reset' of relations with the United States, and the peaceful transition of power back to Putin. The Arctic did not rise to the top of the list.

To regulate development and jurisdiction in the Arctic, it is important to understand that only through cooperation can the Arctic nations overcome the differences between each other and the challenges that the region's changing climate will present. The Arctic Council is a perfect forum in which to arrive at a common language. It gives the Arctic countries an opportunity to solve a variety of problems, from pollution and protection of the environment, to the rights of shipping and sovereignty over the continental shelf. Cooperation in the Arctic might be a good platform for mutual understanding in the other parts of the world. Even with the new major player - a more confident and assertive Russia - the challenges posed by the territorial disputes and new transportation routes have only one path of development, through negotiation and diplomacy. 
THE QUARTERLY JOURNAL

\section{Bibliography}

Byers, Michael. Who Owns the Arctic? Understanding Sovereignty Disputes in the North . Vancouver, BC: Douglas \& McIntyre, 2010.

Hoel, Alf Håkon. "The High North Legal-Political Regime." In Security Prospects in the High North: Geostrategic Thaw or Freeze? Rome: NATO Defense College, 2009.

Stephen, Blank. Russia in the Arctic . Carlisle, PA: Strategic Studies Institute Papers, U.S. Army War College, 2011. 